\title{
IMPLEMENTASI MODEL PEMBELAJARAN KOOPERATIF TIPE TEAMS GAMES TOURNAMENT (TGT) BERBANTU FUN ACCOUNTING BERBASIS LECTORA UNTUK MENINGKATKAN HASIL BELAJAR KOMPETENSI JURNAL PENYESUAIAN SISWA KELAS X AKL 2 SMK NEGERI 7 YOGYAKARTA TAHUN AJARAN 2018/2019
}

\author{
IMPLEMENTATION OF TEAMS GAMES TOURNAMENT (TGT) TYPE COOPERATIVE \\ LEARNING MODEL HELPS BASED LECTORA FUN ACCOUNTING TO IMPROVE \\ LEARNING RESULTS FOR ADJUSTMENT ENTRIES COMPETENCE IN CLASS \\ STUDENTS OF AKL 2 CLASS OF SMK NEGERI 7 YOGYAKARTA ACADEMIC YEAR \\ 2018/2019
}

Oleh: Umianisah Apriliani

Prodi Pendidikan Akuntansi Universitas Negeri Yogyakarta umianisaha@gmail.com

\section{Diana Rahmawati}

Staf Pengajar Jurusan Pendidikan Akuntansi Universitas Negeri Yogyakarta

\begin{abstract}
Abstrak
Penelitian ini bertujuan untuk meningkatkan Hasil Belajar Kompetensi Jurnal Penyesuaian Siswa Kelas X AKL 2 SMK Negeri 7 Yogyakarta Tahun Ajaran 2018/2019 dengan Implementasi Model Pembelajaran Kooperatif Tipe Teams Games Tournaments (TGT) berbantu Fun Accounting berbasis Lectora. Media pembelajaran ini dikembangkan oleh Kartika Bunga pada tahun 2018.

Penelitian ini merupakan Penelitian Tindakan Kelas yang dilaksanakan dalam dua siklus. Setiap siklus terdiri dari tahap perencanaan, pelaksanaan, pengamatan, dan refleksi. Subjek penelitian ini adalah siswa kelas X AKL 2 SMK Negeri 7 Yogyakarta Tahun Ajaran 2018/2019 yang berjumal 32 siswa. Teknik pengumpulan data yang digunakan pada penelitian ini adalah dokumentasi, tes dan catatan lapangan. Instrumen yang digunakan dalam penelitian ini yaitu dokumen, lembar tes dan catatan lapangan.

Hasil penelitian ini menunjukkan rata-rata Hasil Belajar Kompetensi Jurnal Penyesuaian pada pre test siklus I sebesar 33,57 meningkat menjadi sebesar 72,68 pada post test atau meningkat sebesar 39,11. Peningkatan ketuntasan Hasil Belajar Kompetensi Jurnal Penyesuaian pre test siklus I sebesar $6,45 \%$ meningkat menjadi $64,52 \%$ pada post test atau meningkat sebesar 58,07\%. Pada siklus II, nilai rata-rata Hasil Belajar Kompetensi Jurnal Penyesuaian pada pre test sebesar 35,80 meningkat menjadi sebesar 80,09 pada post test atau meningkat sebesar 44,30. Pada siklus II, ketuntasan Hasil Belajar Kompetensi Jurnal Penyesuaian pada pre test $0,00 \%$ meningkat menjadi $78,13 \%$ pada post test atau meningkat sebesar $78,13 \%$. Berdasarkan peningkatan nilai rata-rata dan peningkatan ketuntasan Hasil Belajar Kompentensi Jurnal Penyesuaian dari siklus I ke siklus II, maka hipotesis tindakan yang berbunyi "Implementasi Model Pembelajaran Kooperatif Tipe Teams Games Tournament (TGT) Berbantu Fun Accounting Berbasis Lectora dapat Meningkatkan Hasil Belajar Kompetensi Jurnal Penyesuaian Siswa Kelas X AKL 2 SMK Negeri 7 Yogyakarta Tahun Ajaran 2018/2019” dinyatakan diterima.
\end{abstract}


Kata kunci: Hasil Belajar Kompetensi Jurnal Penyesuaian, Model Pembelajaran Kooperatif Tipe Team Games Tournament (TGT) Berbantu Fun Accounting Berbasis Lectora

\begin{abstract}
This study aims to improve the Learning Results for Adjustment Entries Competence in Class X AKL 2 Students of SMK Negeri 7 Yogyakarta in the 2018/2019 Academic Year with the Implementation of the Teams Games Tournaments (TGT) Type Cooperative Learning Model assisted by Lectora-based Fun Accounting. This learning media was developed by Kartika Bunga in 2018.

This research is a Class Action Research conducted in two cycles. Each cycle consists of the stages of planning, implementation, observation, and reflection. The subjects of this study are 32 students of class X AKL 2 SMK Negeri 7 Yogyakarta Academic Year 2018/2019. Data collection techniques used in this study are documentation, tests and field notes. The instrumentsthat is used in this study are documents, test sheets and field notes.

The results of this study indicate average Learning Results for Adjustment Entries Competence in the first cycle pre test of 33.57 increased to 72.68 in the post test or increased by 39.11. Improvement of completeness Learning Results for Adjustment Entries Competence of the first cycle pre test of $6.45 \%$ increased to $64.52 \%$ in the post test or increased by $58.07 \%$. In the second cycle, the average score of Learning Results for Adjustment Entries Competence for the pre test of 35.80 increased to 80.09 in the post test or increased by 44.30 . In the second cycle, the completeness of the Adjustment Entries Competence Completion Results in the pre test $0.00 \%$ increased to $78.13 \%$ in the post test or increased by $78.13 \%$. Based on the increase in the average value and improvement in completeness Learning Results for Adjustment Entries Competence from cycle I to cycle II, the action hypothesis that reads "Implementation Cooperative Learning Model Teams Games Tournaments (TGT) Helped by Lectora-based Fun Accounting can improve Learning Results for Adjustment Entries Competence in Class X AKL 2 Students of SMK Negeri 7 Yogyakarta in the 2018/2019 Academic Year" was declared accepted.
\end{abstract}

Keywords: Learning Results Adjustment Entries Competence, Cooperative Learning Model Team Games Tournament Type (TGT) assisted by Lectora-based Fun Accounting

\section{PENDAHULUAN}

Perkembangan ilmu pengetahuan dan teknologi informasi menuntut pergeseran paradigma pembelajaran konvensional menuju pembelajaran berbasis teknologi. Disisi lain perkembangan ilmu dan teknologi sebagai pendukung pendidikan belum dapat diaplikasikan secara optimal dalam proses pembelajaran. Penerapan pembelajaran konvensional, di mana guru sebagai sumber utama pengetahuan, harus diubah dan dibenahi sehingga guru berperan sebagai fasilitator. Guru dapat menciptakan pembelajaran yang menyenangkan dengan memanfaatkan teknologi yang ada, sehingga peserta didik dapat menggali potensi yang dimiliki.

Guru memegang peranan yang sangat penting dalam proses pembelajaran. Peran guru tidak hanya sebagai perencana dan pelaksana pembelajaran, guru juga berperan dalam menilai proses dan hasil belajar peserta didik melalui kegiatan evaluasi. Menurut Sudjana (2016: 3), hasil belajar merupakan perubahan tingkah laku yang terjadi dalam diri peserta didik dan mencakup bidang kognitif, afektif, dan psikomotorik. Ketiga bidang tersebut 
merupakan objek penilaian hasil belajar. Namun demikian, di antara ketiga bidang tersebut, bidang kognitiflah yang paling banyak dinilai oleh para guru karena berkaitan dengan kemampuan para siswa dalam menguasai isi bahan pengajaran (Sudjana, 2016: 23). Melalui kegiatan evaluasi inilah keberhasilan pendidikan dapat diukur.

Berdasarkan hasil wawancara yang dilakukan dengan siswa kelas $\mathrm{X}$ AKL 2 SMK Negeri 7 Yogyakarta Tahun Ajaran 2018/2019 pada 10 Oktober 2018, siswa merasa bosan dengan pembelajaran karena guru hanya menggunakan model pembelajaran ceramah, power point, dan buku paket sebagai media pembelajaran. Belum diterapkan model pembelajaran dan media pembelajaran yang mendorong proses pembelajaran berpusat pada siswa. Pembelajaran yang masih berpusat pada guru (teacher centered) sehingga guru masih menjadi sumber utama dalam pembelajaran. Penggunaan metode ini secara terus menerus menimbulkan kebosanan pada siswa. Kegiatan dalam proses pembelajaran hampir seluruhnya didominasi oleh guru. Guru biasanya menyampaikan materi pembelajaran dibantu dengan media power point kemudian siswa diarahkan untuk mengerjakan latihan soal. Guru mengalami kesulitan menerapkan model pembelajaran yang inovatif dan sesuai dengan kebutuhan sehingga siswa sehingga dapat mengikuti pembelajaran dengan baik.

Berdasarkan hasil PAS (Penilaian Akhir Semester) yang diperoleh pada 19 Desember 2018 dari guru mata pelajaran Akuntansi Dasar. Didapat data bahwa dari 3 kelas X AKL (Akuntansi dan Keuangan Lembaga) yang ada di SMK Negeri 7 Yogyakarta Tahun Ajaran 2018/2019 masih banyak siswa yang belum tuntas Kriteria Ketuntansan Minimal (KKM) yang telah ditetapkan yaitu 75. Kelas X AKL 1 terdapat $23(71,88 \%)$ dari 32 siswa belum mencapai KKM dan $9(28,12 \%)$ dari 32 siswa yang telah memenuhi KKM. Kelas X AKL 2 terdapat $27(84,37 \%)$ dari 32 siswa belum memenuhi KKM dan $5(15,63 \%)$ dari 32 siswa yang telah mencapai KKM. Kelas X AKL 3 terdapat $23(74,19 \%)$ dari 31 siswa belum mencapai KKM dan $8(25,81 \%)$ dari 31 siswa yang telah mencapai KKM. Hal tersebut menunjukkan bahwa proses pembelajaran belum dapat dikatakan berhasil karena peserta didik yang telah mencapai KKM masih kurang dari $75 \%$ dari jumlah peserta didik di kelas tersebut. Peneliti memilih kelas X AKL 2 sebagai objek penelitian karena melihat hasil PAS kelas X AKL 2 merupakan kelas yang paling banyak siswa yang belum mencapai KKM, yaitu sebanyak $26(81,25 \%)$ dari 32 siswa.

Terdapat banyak faktor yang memengaruhi hasil belajar yang diperoleh peserta didik di kelas. Mulai dari faktor dalam diri peserta didik (internal) sampai faktor dari luar atau lingkungan sekitar (eksternal). Faktor dalam diri peserta didik (internal) diantaranya yaitu motivasi, keadaan jasmani, keadaan psikis, dan lain sebagainya. Faktor dari luar diri peserta didik (eksternal) diantaranya yaitu lingkungan teman sebaya, suasana belajar, dan lain sebagainya. Salah satu faktor yang memengaruhi hasil belajar adalah model pembelajaran yang digunakan pada saat proses pembelajaran berlangsung. Pemilihan model pembelajaran menjadi hal yang penting, karena model pembelajaran dapat dijadikan pilihan dalam pelaksanaan pembelajaran yang efisien untuk mencapai tujuan pembelajaran (Rusman, 2016: 133). Salah satu model pembelajaran yang dapat diterapkan oleh guru pada saat proses pembelajaran adalah model pembelajaran kooperatif. Model pembelajaran kooperatif dapat diterapkan untuk mengurangi ketergantungan siswa terhadap guru, mengembangkan kemampuan mengungkapkan ide atau gagasan, memberdayakan siswa, meningkatkan prestasi, dan meningkatkan aktivitas belajar siswa (Sanjaya, 2013: 249-250). Gillies (2004: 197-213), mengemukakan bahwa dalam pelaksanaan pembelajaran kooperatif peserta didik akan lebih terstruktur dalam 
belajar dan mengerjakan tugas, peserta didik dapat memberikan bantuan apabila teman dalam kelompoknya mengalami kesulitan belajar.

Ada berbagai macam model pembelajaran kooperatif. Salah satu model pembelajaran kooperatif yang dapat digunakan oleh guru untuk meningkatkan Hasil Belajar adalah Model Pembelajaran Kooperatif Tipe Teams Games Tournament. Menurut Suarjana (2000:10) menyebutkan bahwa salah satu kelebihan Model Pembelajaran Kooperatif Tipe Teams Games Tournament adalah memperoleh hasil belajar yang lebih baik. Pelaksanaan Model Pembelajaran Kooperatif Tipe Teams Games Tournament menggunakan turnamen akademik, dengan menggunakan kuis-kuis dan sistem skor kemajuan individu, dimana para siswa berlomba sebagai wakil tim mereka dengan anggota tim lain yang kinerja akademik sebelumnya setara seperti mereka (Slavin, 2010: 163-165). Teams Games Tournaments (TGT) menawarkan suasana yang menyenangkan dalam kegiatan pembelajaran yang dikemas dalam bentuk turnamen atau kompetisi yang diharapkan hasil belajar siswa dapat mengalami peningkatan. Model pembelajaran yang melibatkan peran siswa sebagai tutor sebaya, mengandung unsur permainan yang bisa meningkatkan semangat belajar.

Model pembelajaran Teams Games Tournaments (TGT) perlu didukung oleh media pembelajaran agar dalam penerapanya dapat membangkitkan ketertarikan siswa dalam pembelajaran. Lectora Inspire Software merupakan media pembelajaran berbasis komputer memuat display yang berisi teks, gambar, suara, animasi, dan video. Fun Accounting berbasis Lectora merupakan media pembelajaran interaktif yang dikembangkan oleh Kartika Bunga Nadhya Noor (2018) yang berisi materi jurnal penyesuaian. Fun Accounting berbasis Lectora ialah media pembelajaran yang menggunakan format .exe sehingga pengguna dapat menggunakan media pembelajaran tanpa perlu untuk koneksi internet atau instal perangkat. Adanya pendukung LCD dan proyektor di ruang kelas SMK Negeri 7 Yogyakarta sehingga dapat ditayangkan sebagai media pembelajaran di dalam kelas.

Mata pelajaran Akuntansi Dasar adalah salah satu mata pelajaran yang harus dikuasai oleh siswa SMK jurusan Akuntansi. Ketika seorang siswa tidak mampu memahami akuntansi dasar maka mereka akan mengalami kesulitan untuk memahami materi selanjutnya. Kompetensi dasar yang sulit untuk diajarkan kepada siswa, yaitu jurnal penyesuaian. Siswa sering merasa bingung dan mengalami kesulitan dalam memahami materi, oleh karena itu guru harus berusaha lebih keras untuk menjelaskan materi jurnal penyesuaian.

Fun Accounting berbasis Lectora digunakan sebagai media pembelajaran dalam penerapanan Model pembelajaran Teams Games Tournaments (TGT). Mengemas materi pembelajaran Jurnal Penyesuaian dan latihan soal dalam Lectora yang disajikan dalam pembelajaran yang menyenangkan dengan model pembelajaran Teams Games Tournaments (TGT). Penerapan model pembelajaran Teams Games Tournaments (TGT) dengan Fun Accounting berbasis Lectora akan membuat siswa belajar materi dengan tampilan yang menarik dalam Fun Accounting dan memahami penerapan jurnal penyesuaian melalui turnamen.

Berdasarkan latar belakang masalah yang telah diuraikan, peneliti bermaksud melakukan penelitian tindakan kelas dengan judul "Implementasi Model Pembelajaran Model Kooperatif Tipe Teams Games Tournaments (TGT) Berbantu Fun Accounting Berbasis Lectora untuk Meningkatkan Hasil Belajar Kompetensi Jurnal Penyesuaian Siswa Kelas X AKL 2 SMK Negeri 7 Yogyakarta Tahun Ajaran 2018/2019”. 


\section{METODE PENELITIAN \\ Desain Penelitian}

Penelitian yang dilakukan merupakan jenis Penelitian Tindakan Kelas (PTK) dalam bentuk kolaboratif dengan guru mata pelajaran Akuntansi Dasar Kelas X AKL 2 SMK Negeri 7 Yogayakarta Tahun Ajaran 2018/2019. Guru bertindak sebagai praktisi yang menjalankan skenario pembelajaran yang telah dirancang bersama peneliti. Penelitian ini dimulai dari tahap perencanaan setelah ditemukannya masalah dalam pembelajaran, dilanjutkan dengan pelaksanaan tindakan, pengamatan, dan refleksi.

\section{Waktu dan Tempat Penelitian}

Penelitian ini dilaksanakan di Kelas X AKL 2 SMK Negeri 7 Yogyakarta yang beralamat di Jalan Gowongan Kidul Blok JT3 No.416, Gowongan, Jetis, Kota Yogyakarta, Daerah Istimewa Yogyakarta. Waktu penelitian dilaksanakan bulan Januari-Februari 2019.

\section{Subjek dan Objek Penelitian}

Subjek penelitian ini adalah siswa kelas X AKL 2 SMK Negeri 7 Yogyakarta Tahun Ajaran 2018/2019 yang berjumlah 32 siswa dan objek penelitian adalah Hasil Belajar Kompetensi Jurnal Penyesuaian siswa dengan Implementasi Model Pembelajaran Kooperatif Tipe Teams Games Tournament (TGT) Berbantu Fun Accounting Berbasis Lectra.

\section{Prosedur}

Berikut adalah prosedur penelitian yang akan dilakukan:

a. Siklus I

\section{1) Perencanaan}

Pada tahap ini, peneliti menyiapkan berbagai hal yang dibutuhkan dalam pelaksanaan penelitian, yaitu:

a) Membuat Rencana Pelaksanaan Pembelajaran (RPP) Akuntansi Dasar Kompetensi Jurnal Penyesuaian dengan menggunakan
Model Pembelajaran Kooperatif Tipe Teams Games Tournament (TGT) berbantu Fun Accounting berbasis Lectora yang dikonsultasikan dengan guru Kelas X Mata Pelajaran Akuntansi Dasar SMK Negeri 7 Yogyakarta.

b) Membuat alokasi waktu pelaksanaan kegiatan pembelajaran dengan implementasi Model Pembelajaran Kooperatif Tipe Teams Games Tournament (TGT) Berbantu Fun Accounting Berbasis Lectora untuk masing-masing tahapan.

c) Menyiapkan media pembelajaran yaitu Fun Accounting berbasis Lectora yang didalamnya telah terdapat materi dan soal.

d) Menyusun instrumen penelitian berupa tes yang meliputi pre test dan post test.

e) Membagi siswa ke dalam 8 kelompok secara heterogen berdasarkan kemampuan akademiknya.

f) Membuat soal yang akan digunakan untuk turnamen beserta kunci jawaban dan pembahasannya dalam power point. Soal turnamen yang dibuat berjumlah 8 soal uraian ditambah 5 soal cadangan. Soal Cadangan digunakan apabila dalam pelaksanaan turnamen belum dapat di tentukan juaranya karena ada kelompok yang memperoleh skor seri.

g) Menyiapkan format catatan lapangan.

h) Menyiapkan 4 buah spidol, kertas HVS, nomor meja, kartu rekap skor, dan juga name tag yang berisi nomor presensi siswa.

i)Mengkonsultasikan kepada guru Kelas X Mata Pelajaran Akuntansi Dasar SMK Negeri 7 Yogyakarta mengenai semua persiapan yang telah dilakukan. 
2) Pelaksanaan

Pada tahap pelaksanaan, yang dilakukan adalah melaksanakan semua persiapan yang telah dilakukan. Pada tahap ini dilaksanakan Implementasi Model Pembelajaran Kooperatif Tipe Teams Games Tournament (TGT) Berbantu Fun Accounting Berbasis Lectora. Pelaksanaan tindakan penelitian ini bersifat fleksibel, artinya jika terjadi perubahan selama proses penelitian berlangsung, maka dicatat dalam catatan lapangan yang menyesuaikan dengan kondisi atau keadaan yang terjadi di lapangan nantinya.

3) Pengamatan

Pengamatan dilakukan selama pembelajaran dengan Implementasi Model Pembelajaran Kooperatif Tipe Teams Games Tournament (TGT) Berbantu Fun Accounting Berbasis Lectora. Pengamatan ini dilakukan dengan mengamati proses pembelajaran. Peneliti juga dibantu oleh satu orang observer lainnya yang juga mencatat semua hal yang diperlukan untuk menunjang penelitian.

4) Refleksi

Tahap refleksi, peneliti melakukan analisis data yang telah dikumpulkan sebelumnya selama proses pembelajaran berlangsung dan dilihat dari hasil pre test, post test. Hal ini dilakukan untuk mengetahui kelebihan dan kekurangan pelaksanaan kegiatan pembelajaran. Hasil dari refleksi ini digunakan untuk memperbaiki kegiatan yang akan dilaksanakan pada siklus II.

b. Siklus II

1) Perencanaan

Tahap perencanaan pada siklus II secara garis besar sama dengan tahap perencanaan pada siklus I. Perbedaannya tahap perencanaan yang dilaksanakan pada siklus II ini mengacu pada refleksi yang telah dilakukan pada siklus I sehingga terjadi perbaikan untuk memperlancar pelaksanaan implementasi Model Pembelajaran Kooperatif Tipe Teams Games Tournament (TGT) Berbantu Fun Accounting Berbasis Lectora pada siklus II.

2) Pelaksanaan

Tahap pelaksanaan siklus II dilakukan sama dengan pelaksanaan pada siklus I dengan memperbaiki kekurangan dan hambatan yang terjadi pada pelaksanaan siklus I.

3) Pengamatan

Tahap pengamatan yang dilakukan sama dengan tahap pengamatan siklus I. Pengamatan dilaksanakan selama proses pembelajaran berlangsung.

4) Refleksi

Pada tahap ini dilakukan evaluasi mengenai keseluruhan pelaksanaan Implementasi Model Pembelajaran Kooperatif Tipe Teams Games Tournament (TGT) Berbantu Fun Accounting Berbasis Lectora. Pada tahap ini digunakan untuk mengetahui peningkatan Hasil Belajar Kompetensi Jurnal Penyesuaian dari siklus I dan siklus II. Apabila terjadi peningkatan Hasil Belajar dari siklus I ke siklus II maka tidak diadakan siklus tambahan, namun apabila belum terjadi peningkatan Hasil Belajar Kompetensi Jurnal Penyesuaian maka akan dilaksanakan siklus selanjutnya sampai tujuan tersebut tercapai.

\section{Teknik Pengumpulan Data}

a. Dokumentasi

Dokumentasi digunakan sebagai data pendukung yang diperoleh selama kegiatan penelitian berlangsung. Dokumentasi juga digunakan sebagai penguat data yang diperoleh selama penelitian.

b. Tes

Tes Hasil Belajar Kompetensi Jurnal Penyesuaian diukur berdasarkan Kriteria 
Ketuntasan Minimal yang telah ditetapkan yang harus dicapai oleh siswa. Penelitian ini tes yang diberikan kepada siswa adalah tes awal (pre test) dan tes akhir (post test). Tes awal berfungsi untuk menilai kemampuan awal peserta didik mengenai materi pelajaran sebelum pembelajaran diberikan, sedangkan tes akhir berfungsi untuk menilai kemampuan peserta didik setelah pembelajaran diberikan. Tes akhir (post test) yang diberikan pada akhir siklus I dan siklus II digunakan untuk menunjukkan Hasil Belajar Kompetensi Jurnal Penyesuaian yang dicapai siswa pada setiap siklus, yang bertujuan untuk mengetahui apakah terdapat peningkatan Hasil Belajar Kompetensi Jurnal Penyesuaian setelah adanya penerapan Model Pembelajaran Kooperatif Tipe Teams Games Tournament (TGT) Berbantu Fun Accounting Berbasis Lectora.

c. Catatan Lapangan

Catatan lapangan digunakan untuk memperoleh data berbagai aspek pembelajaran di kelas, suasana kelas, pengelolaan kelas, hubungan interaksi guru dengan siswa, dan interaksi siswa dengan siswa selama proses pembelajaran dengan penerapan Model Pembelajaran Kooperatif Tipe Teams Games Tournament (TGT) Berbantu Fun Accounting Berbasis Lectora.

\section{Instrumen Penelitian}

Instrumen penelitian dalam penelitian ini adalah sebagai berikut:

a. Dokumen

Dokumen-dokumen yang digunakan dalam penelitian ini adalah daftar nilai, daftar presensi siswa, silabus, RPP, dan dokumentasi berupa foto saat proses pembelajaran sedang berlangsung.

b. Lembar Tes

Menurut Arifin (2013: 118) tes merupakan suatu teknik atau cara yang digunakan sebagai alat pengukuran, yang di dalamnya terdapat berbagai pertanyaan, pernyataan, atau serangkaian tugas yang harus dikerjakan oleh peserta didik untuk mengukur atau menilai peserta didik. Tes adalah alat yang digunakan untuk mengukur kemampuan peserta didik dalam memahami suatu materi yang telah dipelajari. Dalam penelitian ini tes yang diberikan kepada siswa adalah tes awal (pre test) dan tes akhir (post test).

c. Catatan Lapangan

Catatan lapangan digunakan untuk menuliskan berbagai kejadian yang berhubungan dengan penelitian yang terjadi di dalam kelas. Kejadian dapat berupa interaksi yang terjadi antara siswa dengan guru, interaksi antar siswa, pengelolaan kelas, suasana kelas, dan kegiatan penelitian semuanya dapat dilihat lagi pada catatan lapangan ini. Fungsi catatan lapangan adalah untuk melakukan pengecekan dengan data-data yang telah didapatkan.

\section{Validasi}

Peneliti meminta pendapat dari ahli (expert judgement) untuk mengevaluasi alat ukur yang telah dibuat. Ahli inilah yang akan menilai apakah alat ukur telah valid atau tidak. Ahli dalam penelitian ini adalah Ibu Ani Widayati, S.Pd., M.Pd., Ed.D. Dosen Jurusan Pendidikan Akuntansi dan Ibu Titik Komah Nurastuti, S.Pd. guru mata pelajaran Akuntansi Dasar SMK Negeri 7 Yogyakarta.

Hasil expert judgement menunjukkan bahwa RPP siklus I memperoleh nilai ratarata sebesar 55,5 dengan kategori baik dan soal siklus I memperoleh nilai rata-rata sebesar 53 dengan kategori sangat baik. RPP siklus II memperoleh nilai rata-rata sebesar 55,5 dengan kategori baik dan soal siklus II memperoleh nilai rata-rata sebesar 53 dengan kategori sangat baik. Berdasarkan hasil expert judgement instrument penelitian yang digunakan untuk siklus I dan siklus II dikatakan valid atau layak digunakan dalam penelitian. 


\section{Teknik Analisis Data}

a. Analisis Data Deskriptif Kuantitatif

1) Menghitung Peningkatan Hasil Belajar Kompetensi Jurnal Penyesuaian

Peningkatan Hasil Belajar Kompetensi Jurnal Penyesuaian diketahui dengan cara menghitung rata-rata pre test dan post test pada siklus pertama ke post test yang diperoleh melalui rumus:

Rumus Mean:

$$
M e=\frac{\Sigma X_{i}}{n}
$$

Keterangan:

$M e \quad=\operatorname{rata}-\operatorname{rata}($ Mean $)$

$\Sigma X_{i} \quad=$ jumlah semua nilai

$n \quad=$ jumlah siswa

(Sugiyono, 2015:49)

Menghitung persentase kentutasan belajar siswa dengan rumus:

$=\frac{\text { Total siswa mendapat nilai } \geq 75}{\text { Total siswa mengikuti penelitian }}$

(Mulyasa, 2010: 199)

2) Penyajian Data

Setelah data tentang Hail Belajar Siswa Kompetensi Jurnal Penyesuaian diolah, data disajikan dalam bentuk tabel dan grafik sehingga mudah dipahami.

3) Kesimpulan

Kesimpulan dilakukan dengan tujuan untuk menjawab rumusan masalah penelitian apakah Model Pembelajaran Kooperatif Tipe Teams Games Tournament (TGT) Berbantu Fun Accountin Berbasis Lectora dapat Meningkatkan Hasil Belajar Kompetensi Jurnal Penyesuaian Siswa Kelas X AKL 2 SMK Negeri 7 Yogyakarta Tahun Ajaran 2018/2019?
HASIL PENELITIAN DAN PEMBAHASAN

\section{Observasi Awal}

Sebelum melakukan penelitian, peneliti melakukan observasi awal proses pembelajaran di kelas X AKL 2 pada 10 Oktober 2018. Observasi ini dilakukan dengan tujuan untuk mengetahui permasalahan yang terjadi selama proses pembelajaran berlangsung.

Hasil observasi dapat diketahui bahwa ada permasalahan yang perlu dicermati. Permasalahan yang ada yaitu Hasil Belajar Akuntansi Dasar yang masih rendah. Hal ini ditunjukkan dengan hasil PAS (Penilaian Akhir Semester) yang diperoleh pada 19 Desember 2018 dari guru mata pelajaran Akuntansi Dasar. Didapat data bahwa dari 3 kelas AKL yang ada di SMK Negeri 7 Yogyakarta masih banyak siswa yang belum tuntas KKM yang telah ditetapkan yaitu 75 . Kelas X AKL 2 terdapat $27(84,37 \%)$ dari 32 siswa belum memenuhi KKM dan 5 x $1005,63 \%$ ) dari 32 siswa yang telah mencapai KKM. Pembelajaran yang dilaksanakan guru menggunakan model pembelajaran ceramah, power point, dan buku paket sebagai media pembelajaran. Penerapan pembelajaran seperti ini secara terus menerus menimbulkan kebosanan pada siswa. Kegiatan dalam proses pembelajaran hampir seluruhnya didominasi oleh guru. Hal ini yang mengakibatkan Hasil Belajar akuntansinya rendah.

Berdasarkan permasalahan tersebut, diperlukan suatu tindakan untuk meningkatkan Hasil Belajar Akuntansi siswa kelas X AKL 2 SMK Negeri 7 Yogyakarta Tahun Ajaran 2018/2019. Cara yang dilakukan peneliti untuk meningkatkan Hasil Belajar adalah dengan mengimplementasikan Model Pembelajaran Model Kooperatif Tipe Teams Games Tournaments (TGT) Berbantu Fun Accounting berbasis Lectora. Implementasikan Model Pembelajaran Model Kooperatif Tipe Teams Games Tournaments (TGT) Berbantu Fun Accounting Berbasis Lectora diharapkan 
dapat meningkatkan Hasil Belajar Kompetensi Jurnal Penyesuaian Siswa Kelas $\mathrm{X}$ AKL 2 SMK Negeri 7 Yogyakarta Tahun Ajaran 2018/2019.

\section{Laporan Siklus 1}

Berikut pengamatan Hasil Belajar Kompetensi Jurnal Penyesuaian dilakukan berdasarkan hasil pre test dan post test siklus I. Kriteria Ketuntasan Minimal (KKM) pada materi ini adalah sebesar 75 .

Tabel 1. Hasil Belajar Kompetensi Jurnal Penyesuaian Siklus I

\begin{tabular}{|c|c|c|c|c|c|}
\hline \multirow[t]{2}{*}{ Kategori Nilai } & \multicolumn{2}{|c|}{ Pre Test } & \multicolumn{2}{|c|}{ Post Test } & \multirow{2}{*}{$\begin{array}{c}\text { Peningkatan Rata } \\
\text { rata Kelas } \\
\end{array}$} \\
\hline & $F$ & $\%$ & $\mathrm{~F}$ & $\%$ & \\
\hline$N \geq 75$ & 2 & 6,45 & 20 & 64,52 & \\
\hline $\mathrm{N} \leq 75$ & 29 & 93,55 & 11 & 35,48 & \\
\hline Jumlah & 31 & 100 & 31 & 100 & \\
\hline Rata-rata Kelas & \multicolumn{2}{|c|}{33,57} & \multicolumn{2}{|c|}{72,68} & 39,11 \\
\hline
\end{tabular}

Keterangan: $\mathrm{N}=$ Nilai

$\mathrm{F}=$ Frekuensi

Berdasarkan data di atas, dapat disimpulkan bahwa rata-rata nilai siswa pada siklus I meningkat dari nilai rata-rata pre test sebesar 33,57 menjadi sebesar 72,68 pada post test atau meningkat sebesar 39,11. Jika digambarkan dalam bentuk diagram, maka nilai Hasil Belajar Kompetensi Jurnal Penyesuaian siklus I dapat dilihat pada Gambar 1.

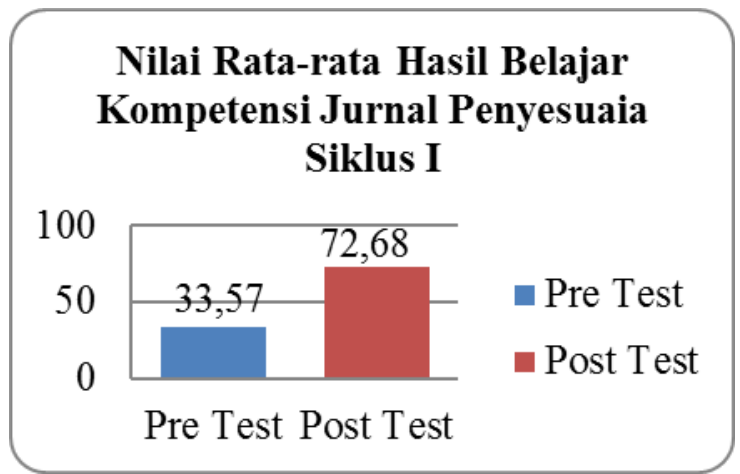

\section{Gambar 1. Nilai Rata-rata Hasil Belajar Kompetensi Penyesuaian Siklus I \\ Jurnal}

Ketuntasan belajar pre test menunjukkan bahwa terdapat 2 siswa $(6,45 \%)$ yang telah mencapai KKM, sedangkan ketuntasan belajar post test menunjukkan bahwa terjadi peningkatan jumlah siswa yang mencapai KKM, yaitu menjadi 20 siswa $(64,52 \%)$. Jika digambarkan dalam bentuk diagram, maka ketuntasan Hasil Belajar Akuntansi pada siklus I dapat dilihat pada Gambar 2 .

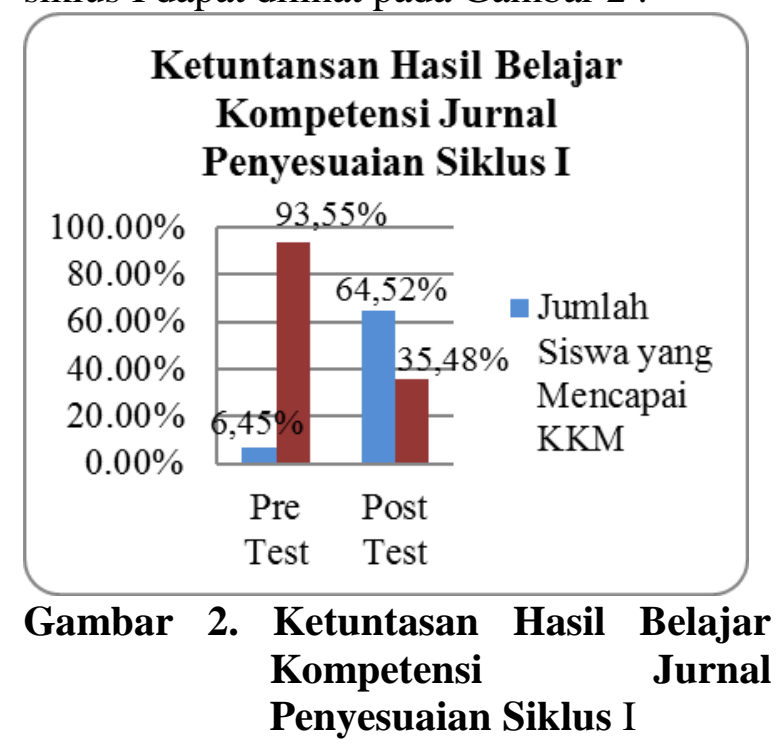

\section{Laporan Siklus II}

Pelaksanaan siklus II dilakukan karena pada siklus I ketuntasan hasil belajar yang diperoleh belum mencapai indikator keberhasilan yang telah ditetapkan yaitu $75 \%$ siswa yang mencapai KKM. Hasil belajar siswa yang mencapai KKM sebanyak 20 dari 31 siswa atau sebesar $64,52 \%$. Hasil refleksi yang di buat pada siklus I diterapkan pada siklus II dengan 
harapan ketuntansan belajar pada siklus II dapat mencapai indikator keberhasilan.

Pengamatan Hasil Belajar Kompetensi Jurnal Penyesuaian dilakukan berdasarkan hasil pre test dan post test siklus II. Kriteria Ketuntasan Minimal (KKM) pada materi ini adalah sebesar 75 .

Tabel 2. Hasil Belajar Kompetensi Jurnal Penyesuaian Siklus II

\begin{tabular}{|c|c|c|c|c|c|}
\hline \multirow[t]{2}{*}{ Kategori Nilai } & \multicolumn{2}{|c|}{ Pre Test } & \multicolumn{2}{|c|}{ Post Test } & \multirow{2}{*}{$\begin{array}{c}\text { Peningkatan } \\
\text { Rata-rata Kelas }\end{array}$} \\
\hline & $\mathrm{F}$ & $\%$ & $\mathrm{~F}$ & $\%$ & \\
\hline$N \geq 75$ & 0 & 0,00 & 25 & 78,13 & \\
\hline $\mathrm{N} \leq 75$ & 32 & 100,00 & 7 & 21,88 & \\
\hline Jumlah & 32 & 100 & 32 & 100 & \\
\hline Rata-rata Kelas & \multicolumn{2}{|c|}{35,80} & \multicolumn{2}{|c|}{80,09} & 44,30 \\
\hline
\end{tabular}

Keterangan: $\mathrm{N}=$ Nilai

$\mathrm{F}=$ Frekuensi

Berdasarkan data di atas, dapat disimpulkan bahwa rata-rata nilai siswa pada siklus II meningkat dari nilai rata-rata pre test sebesar 35,80 menjadi sebesar 80,09 pada post test atau meningkat sebesar 44,30. Jika digambarkan dalam bentuk diagram, maka nilai Hasil Belajar Kompetensi Jurnal Penyesuaian siklus II dapat dilihat pada Gambar 3.

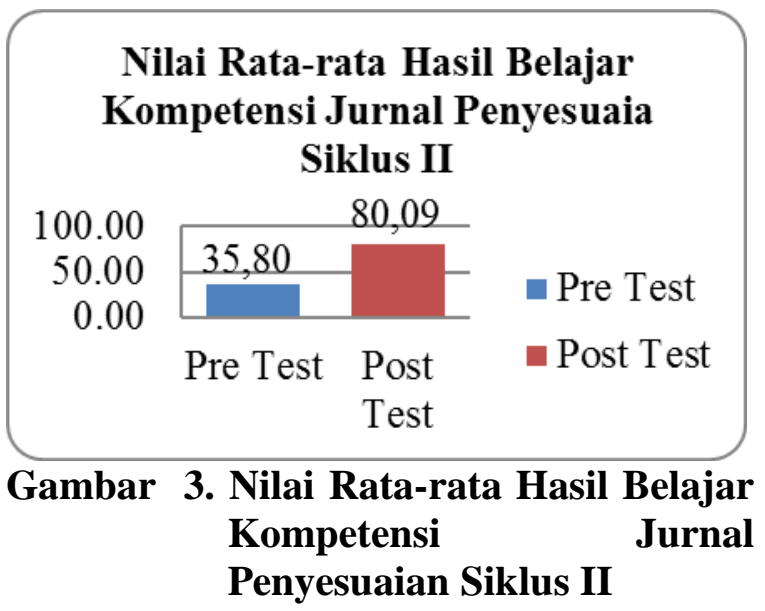

Ketuntasan belajar pre test menunjukkan bahwa tidak satupun siswa yang telah mencapai KKM, sedangkan ketuntasan belajar post test menunjukkan bahwa terjadi peningkatan jumlah siswa yang mencapai KKM, yaitu menjadi 28 siswa $(78,13 \%)$. Hasil pre test dan post test menunjukkan bahwa jumlah siswa yang mencapai KKM sudah melebihi $75 \%$ yaitu sebesar 78,13\%. Jika digambarkan dalam bentuk diagram, maka ketuntasan Hasil Belajar Akuntansi pada siklus II dapat dilihat pada Gambar 4.

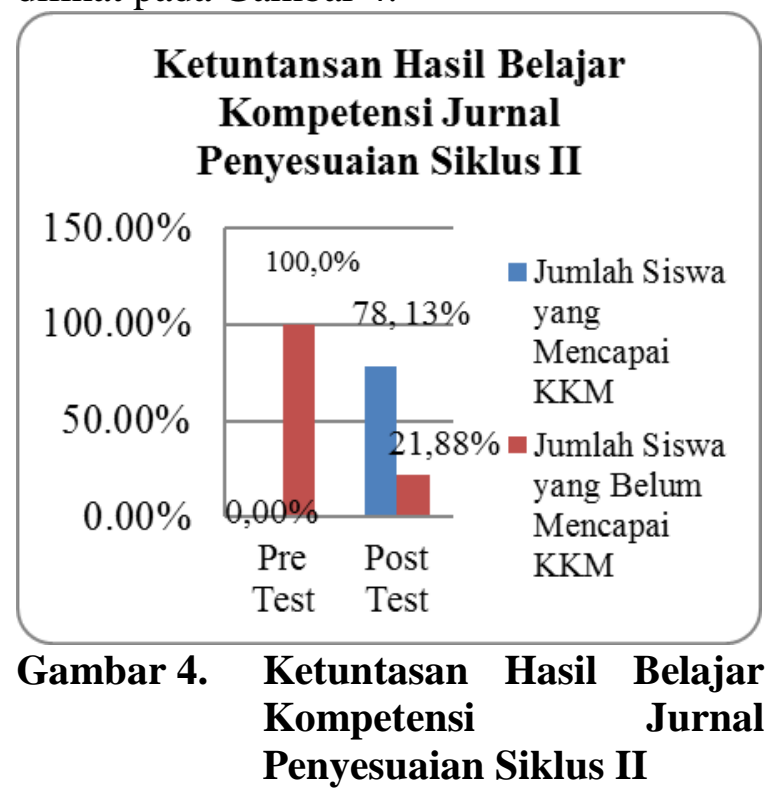

\section{Hasil Penelitian}

Pelaksanaan proses pembelajaran dengan Implementasi Model Pembelajaran Kooperatif tipe Teams Games Tournaments (TGT) Berbantu Fun Accounting Berbasis Lectora pada siklus I dan siklus II menunjukkan adanya peningkatan Hasil Belajar Kompetensi Jurnal Penyesuaian khususnya ranah kognitif. Peningkatan nilai rata-rata Hasil Belajar Kompetensi Jurnal 
Penyesuaian pada siklus I dan siklus II dapat dilihat pada tabel 3 .

Tabel 3. Peningkatan Nilai Rata-rata Hasil Belajar Kompetensi Jurnal Penyesuaian pada Siklus I dan Siklus II

\begin{tabular}{|c|c|l|r|}
\hline Siklus & \multicolumn{2}{|c|}{$\begin{array}{l}\text { Nilai Rata-rata } \\
\text { Kelas }\end{array}$} & \multirow{2}{*}{ Peningkatan } \\
\cline { 2 - 3 } & $\begin{array}{l}\text { Pre } \\
\text { Test }\end{array}$ & $\begin{array}{l}\text { Post } \\
\text { Test }\end{array}$ & \\
\hline I & 33,57 & 72,68 & 39,11 \\
\hline II & 35,80 & 80,09 & 44,30 \\
\hline
\end{tabular}

Peningkatan Hasil Belajar Akuntansi di atas juga dapat dilihat pada diagram di bawah ini:

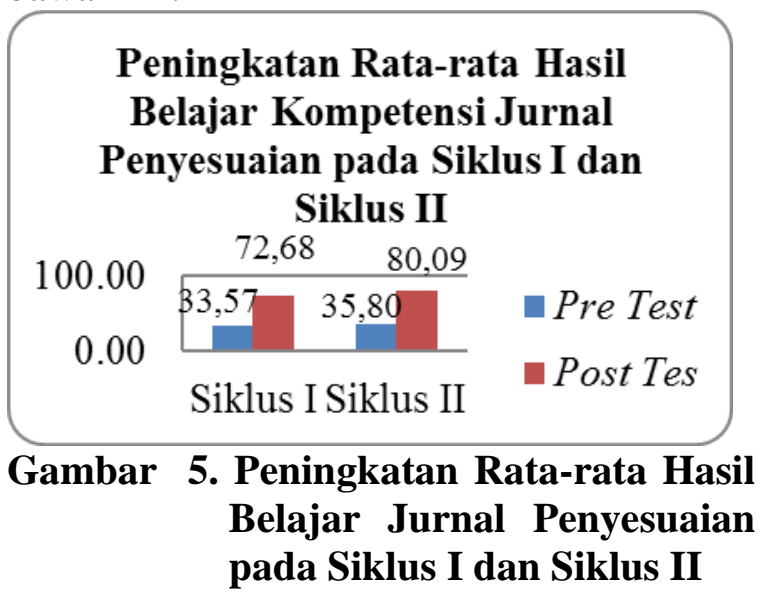

Berdasarkan tabel dan diagram di atas, diketahui bahwa telah terjadi peningkatan rata-rata Hasil Belajar Kompetensi Jurnal Penyesuaian pada siklus I dan siklus II setelah adanya implementasi Model Pembelajaran Kooperatif Tipe Teams Games Tournament (TGT) Berbantu Fun Accounting Berbasis Lectora. Rata-rata Hasil Belajar Kompetensi Jurnal Penyesuaian pada pre test siklus I sebesar 33,57 meningkat menjadi sebesar 72,68 pada post test atau meningkat sebesar 39,11. Pada siklus II, nilai rata-rata Hasil Belajar Kompetensi Jurnal Penyesuaian pada pre test sebesar 35,80 meningkat menjadi sebesar 80,09 pada post test atau meningkat sebesar 44,30. Nilai rata-rata Hasil Belajar Kompetensi Jurnal Penyesuaian dari pre test ke post test mengalami peningkatan. Data tersebut membuktikan bahwa implementasi Model Pembelajaran Kooperatif Tipe Teams Games Tournament berbantu Fun Accounting berbasis Lectora dapat meningkatkan Hasil Belajar Akuntansi.

Peningkatan Hasil Belajar Kompetensi Jurnal Penyesuaian juga dapat dilihat dari peningkatan ketuntasan Hasil Belajar Kompetensi Jurnal Penyesuaian pada siklus I dan siklus II. Berikut ini adalah tabel ketuntasan Hasil Belajar Akuntansi pada siklus I dan siklus II:

Tabel 4. Peningkatan Ketuntasan Hasil Belajar Kompetensi Jurnal Penyesuaian pada Siklus I dan Siklus II

\begin{tabular}{|c|c|c|r|r|r|}
\hline \multirow{3}{*}{ Siklus } & \multicolumn{4}{|c|}{$\begin{array}{c}\text { Ketuntasan Hasil Belajar Kompetensi } \\
\text { Jurnal Penyesuaian }\end{array}$} & Peningkatan \\
\cline { 2 - 6 } & \multicolumn{2}{|c|}{ Pre Test } & \multicolumn{2}{c|}{ Post Test } & \\
\cline { 2 - 6 } & $\mathrm{N} \geq 75$ & $\%$ & $\mathrm{~N} \geq 75$ & $\%$ & \\
\hline I & 2 & $6,45 \%$ & 20 & $64,52 \%$ & $58,07 \%$ \\
\hline II & 0 & $0,00 \%$ & 25 & $78,13 \%$ & $78,13 \%$ \\
\hline
\end{tabular}

Keterangan: $\mathrm{N}=$ Nilai

Peningkatan ketuntasan Hasil Belajar Kompetensi Jurnal Penyesuaian juga dapat dilihat pada Gambar 6. 


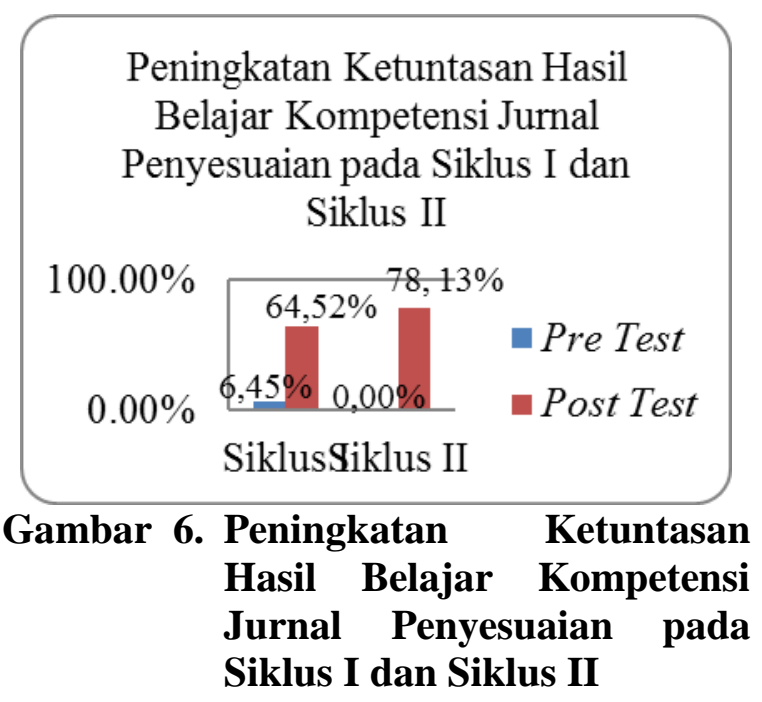

Berdasarkan tabel dan diagram di atas diketahui bahwa telah terjadi peningkatan ketuntasan Hasil Belajar Kompetensi Jurnal Penyesuaian setelah adanya Implementasi Model Pembelajaran Kooperatif Tipe Teams Games Tournament (TGT) Berbantu Fun Accounting Berbasis Lectora. Ketuntasan Hasil Belajar Kompetensi Jurnal Penyesuaian pada pre test siklus I sebesar $6,45 \%$ meningkat menjadi $64,52 \%$ pada post test atau meningkat sebesar 58,07\%. Pada siklus II, ketuntasan Hasil Belajar Akuntansi pada pre test $0,00 \%$ meningkat menjadi $78,13 \%$ pada post test atau meningkat sebesar 78,13\%. Jika ketuntasan Hasil Belajar Kompetensi Jurnal Penyesuaian siklus I dan siklus II dibandingkan, maka peningkatan ketuntasan Hasil Belajar Kompetensi Jurnal Penyesuaian pada siklus II lebih besar dari pada peningkatan yang terjadi pada siklus I. Berdasarkan hasil diatas maka hipotesis tindakan yang berbunyi "Implementasi Model Pembelajaran Kooperatif Tipe Teams Games Tournament (TGT) Berbantu Fun Accounting Berbasis Lectora dapat Meningkatkan Hasil Belajar Kompetensi Jurnal Penyesuaian Siswa Kelas X AKL 2 SMK Negeri 7 Yogyakarta Tahun Ajaran 2018/2019" dinyatakan diterima.

\section{Pembahasan}

Penelitian ini menggunkan tes sebagai instrumen penelitian. Tes Hasil Belajar Kompetensi Jurnal Penyesuaian diukur berdasarkan Kriteria Ketuntasan Minimal yang telah ditetapkan dan harus dicapai oleh siswa yaitu 75. Tes yang diberikan kepada siswa adalah tes awal (pre test) dan tes akhir (post test). Tes awal berfungsi untuk menilai kemampuan awal peserta didik mengenai materi pelajaran sebelum pembelajaran diberikan, sedangkan tes akhir berfungsi untuk menilai kemampuan peserta didik setelah pembelajaran diberikan. Tes akhir (post test) yang diberikan pada akhir siklus I dan siklus II digunakan untuk menunjukkan Hasil Belajar Kompetensi Jurnal Penyesuaian yang dicapai siswa pada setiap siklus, yang bertujuan untuk mengetahui apakah terdapat peningkatan Hasil Belajar Kompetensi Jurnal Penyesuaian setelah adanya penerapan Model Pembelajaran Kooperatif Tipe Teams Games Tournament (TGT) Berbantu Fun Accounting Berbasis Lectora.

Soal pre test dan post test yang digunakan untuk mengetahui Hasil Belajar Kompetensi Jurnal Penyesuaian pada ranah kognitif, yaitu pengetahuan (C1), pemahaman (C2), aplikasi (C3) dan analisis (C4). Pembuatan soal pre test dan post test ini disesuaikan dengan kisi-kisi yang telah dibuat sebelumnya. Soal pre test dan post test pada siklus I berjumlah 6 soal dengan materi siklus akuntansi akhir periode, pengertian jurnal penyesuaian, dasar pencatatan jurnal penyesuaian, dan jenisjenis penyesuaian yang meliputi: beban yang masih harus dibayar, beban dibayar dimuka, penghasilan yang masih harus diterima, dan penyusutan aset tetap. Soal pre test dan post test pada siklus II berjumlah 6 soal dengan materi jenis-jenis penyesuaian yang meliputi pendapatan diterima dimuka, perlengkapan yang digunakan dan taksiran kerugian piutang. Selain itu, pembuatan soal pre test dan post test juga di validasi kepada ahli (expert judgement) yaitu Ibu Ani 
Widayati, S.Pd., M.Pd., Ed.D. Dosen Jurusan Pendidikan Akuntansi dan Ibu Titik Komah Nurastuti, S.Pd. guru mata pelajaran Akuntansi Dasar SMK Negeri 7 Yogyakarta.

Terdapat peningkatan Hasil Belajar Kompetensi Jurnal Penyesuaian setelah adanya penerapan Model Pembelajaran Kooperatif Tipe Teams Games Tournament (TGT) Berbantu Fun Accounting Berbasis Lectora. Rata-rata Hasil Belajar Kompetensi Jurnal Penyesuaian pada pre test siklus I sebesar 33,57 meningkat menjadi sebesar 72,68 pada post test atau meningkat sebesar 39,11. Pada siklus II, nilai rata-rata Hasil Belajar Kompetensi Jurnal Penyesuaian pada pre test sebesar 35,80 meningkat menjadi sebesar 80,09 pada post test atau meningkat sebesar 44,30. Ketuntasan Hasil Belajar Kompetensi Jurnal Penyesuaian pada pre test siklus I sebesar $6,45 \%$ meningkat menjadi $64,52 \%$ pada post test atau meningkat sebesar 58,07\%. Pada siklus II, ketuntasan Hasil Belajar Akuntansi pada pre test $0,00 \%$ meningkat menjadi $78,13 \%$ pada post test atau meningkat sebesar $78,13 \%$. Berdasarkan hasil penelitian di atas dapat disimpulkan bahwa Implementasi Model Pembelajaran Kooperatif Tipe Teams Games Tournament (TGT) Berbantu Fun Accounting Berbasis Lectora dapat meningkatkan Hasil Belajar Kompetensi Jurnal Penyesuaian siswa kelas X AKL 2 SMK Negeri 7 Yogyakarta tahun ajaran 2018/2019. Hasil penelitian ini sejalan dengan teori yang dikemukakan oleh Suarjana (2000:10) yang menyebutkan bahwa salah satu kelebihan Model Pembelajaran Kooperatif Tipe Teams Games Tournament adalah memperoleh hasil belajar yang lebih baik. Hal ini juga sejalan dengan yang dikemukakan oleh Taniredja, T, dkk (2012: 72-73) yang menyebutkan bahwa salah satu kelebihan Model Pembelajaran Kooperatif Tipe Teams Games Tournament adalah meningkatkan pemahaman siswa terhadap materi pembelajaran dan membuat interaksi antar siswa maupun interaksi antara guru dan siswa menjadi lebih hidup dan tidak membosankan.

Penelitian yang telah dilakukan membuktikan bahwa Implementasi Model Pembelajaran Kooperatif tipe Teams Games Tournaments (TGT) Berbantu Fun Accounting Berbasis Lectora dapat meningkatkan Hasil Belajar Kompetensi Jurnal Penyesuaian. Hal ini sejalan dengan penelitian-penelitian yang telah dilakukukan oleh Miftahul Triana Fajri (2011) tentang Implementasi Model Pembelajaran Team Game Tournament (TGT) untuk Meningkatkan Hasil Belajar Kewirausahaan Siswa Kelas X Busana SMK Negeri 6 Purworejo, Nita Lestari (2017) tentang Implementasi Model Pembelajaran Kooperatif Tipe Teams Games Tournament untuk Meningkatkan Aktivitas Belajar dan Hasil Belajar Akuntansi Siswa Kelas XI Akuntansi 3 SMK Negeri 1 Godean Tahun Ajaran 2016/2017, Novita Anggraini Widyastuti (2017) tentang Implementasi Model Pembelajaran Kooperatif Teams Game Tournament (TGT) dengan Perminan Tic Tac Toe untuk Meningkatkan Minat dan Hasil Belajar Ekonomi Siswa Kelas X MIA 4 SMA Negeri 1 Sewon Tahun Ajaran 2016/2017, Hanifah Rachmawati (2018) tentang Implementasi Model Pembelajaran Kooperatif Tipe Team Games Tournament (TGT) dengan Media Pembelajaran Kotak dan Kartu Misteri (Kokami) untuk Meningkatkan Motivasi Belajar dan Hasil Belajar Kelas X Akuntansi di SMK Muhammadiyah 1 Wates Tahun Ajaran 2017/2018.

Data hasil penelitian tersebut menunjukkan bahwa Implementasi Model Pembelajaran Kooperatif Tipe Teams Games Tournament Berbantu Fun Accounting Berbasis Lectora dapat meningkatkan Hasil Belajar Kompetensi Jurnal Penyesuaian. Dengan demikian, hipotesis tindakan dalam penelitian ini yang berbunyi "Implementasi Model Pembelajaran Kooperatif Tipe Teams 
Games Tournament (TGT) Berbantu Fun Accounting Berbasis Lectora dapat Meningkatkan Hasil Belajar Kompetensi Jurnal Penyesuaian Siswa Kelas X AKL 2 SMK Negeri 7 Yogyakarta Tahun Ajaran 2018/2019" dinyatakan sudah terjawab.

\section{SIMPULAN DAN SARAN \\ Simpulan}

Berdasarkan hasil penelitian dan pembahasan pada Bab IV, maka dapat disimpulkan bahwa Implementasi Model Pembelajaran Kooperatif Tipe Teams Games Tournaments (TGT) Berbantu Fun Accounting Berbasis Lectora dapat meningkatkan Hasil Belajar Kompetensi Jurnal Penyesuaian Siswa Kelas X AKL 2 SMK Negeri 7 Yogyakarta Tahun Ajaran 2018/2019 hal ini dibuktikan dengan peningkatan nilai rata-rata Hasil Belajar Kompetensi Jurnal Penyesuaian dan peningkatan ketuntasan Hasil Belajar Kompetensi Jurnal Penyesuaian dari siklus I ke siklus II. Rata-rata Hasil Belajar Kompetensi Jurnal Penyesuaian pada pre test siklus I sebesar 33,57 meningkat menjadi sebesar 72,68 pada post test atau meningkat sebesar 39,11. Pada siklus II, nilai rata-rata Hasil Belajar Kompetensi Jurnal Penyesuaian pada pre test sebesar 35,80 meningkat menjadi sebesar 80,09 pada post test atau meningkat sebesar 44,30. Peningkatan ketuntasan Hasil Belajar Kompetensi Jurnal Penyesuaian pre test siklus I sebesar $6,45 \%$ meningkat menjadi $64,52 \%$ pada post test atau meningkat sebesar 58,07\%. Pada siklus II, ketuntasan Hasil Belajar Akuntansi pada pre test $0,00 \%$ meningkat menjadi $78,13 \%$ pada post test atau meningkat sebesar $78,13 \%$. Berdasarkan peningkatan nilai rata-rata Hasil Belajar Kompentensi Jurnal Penyesuaian dan peningkatan ketuntasan Hasil Belajar Kompentensi Jurnal Penyesuaian dari siklus I ke siklus II, maka hipotesis tindakan yang berbunyi "Implementasi Model Pembelajaran Kooperatif Tipe Teams Games Tournament
(TGT) Berbantu Fun Accounting Berbasis Lectora dapat Meningkatkan Hasil Belajar Kompetensi Jurnal Penyesuaian Siswa Kelas X AKL 2 SMK Negeri 7 Yogyakarta Tahun Ajaran 2018/2019" diterima.

\section{Saran}

a. Bagi Guru

1) Model Pembelajaran Kooperatif Tipe Teams Game Tournament Berbantu Fun Accounting Berbasis Lectora mampu meningkatkan Hasil Belajar siswa, sehingga dapat digunakan sebagai salah satu alternatif model pembelajaran dan media pembelajaran yang dapat diterapkan oleh guru, terutama dalam mata pelajaran Akuntansi Dasar.

2) Sebaiknya guru menggunakan Fun Accounting berbasis Lectora sebagai media pembelajaran agar kegiatan pembelajaran menjadi lebih variatif dan menambah antusias belajar siswa.

3) Guru dapat menggunakan model pembelajaran dan media pembelajaran lainnya untuk mendukung proses pembelajaran Akuntansi Dasar, misalnya penerapan model pembelajaran dengan memanfaatkan penggunaan handphone seperti aplikasi Smart Accounting berbasis android.

b. Bagi Peneliti Selanjutnya

1) Melakukan koordinasi yang lebih baik bersama guru dan siswa sebelum dilaksanakannya penelitian tindakan kelas, agar pada saat pelaksanaan tindakan, guru dan siswa telah memiliki gambaran mengenai apa saja yang harus dilakukan selama proses pembelajaran dengan Implementasi Model Pembelajaran Kooperatif tipe Teams Games Tournaments (TGT) Berbantu Fun Accounting berbasis Lectora. 
2) dapat melakukan penelitian tindakan kelas (PTK) dengan berbagai model pembelajaran dan pemanfaatan media pembelajaran berbasis teknologi untuk menangani permasalahanpermasalahan siswa saat Kegiatan Belajar Mengajar (KBM) berlangsung di era digital, khususnya pada mata pelajaran Akuntansi Dasar.

3) Melakukan penelitian mengenai respon siswa terhadap Implementasi Model Pembelajaran Kooperatif tipe Teams Games Tournaments (TGT) Berbantu Fun Accounting berbasis Lectora.

\section{DAFTAR PUSTAKA}

Arifin, Z. (2013). Evaluasi Pembelajaran. Bandung: PT Remaja Rosdakarya.

Arikunto, S., Suhardjono, \& Supardi (2016). Penelitian Tindakan Kelas. Jakarta: PT Bumi Aksara. . (2016). Dasar-Dasar Evaluasi Pendidikan. Jakarta: PT Bumi Aksara.

Fajrin, M.T. (2011). "Implementasi Model Pembelajaran Team Game Tournament (TGT) untuk Meningkatkan Hasil Belajar Kewirausahaan Siswa Kelas X Busana SMK Negeri 6 Purworejo".Skripsi: FE UNY.

Gillies, M Robyn. (2004).” The Effect of Cooperative Learning on Junior High School Student During Small Group Learning". Journal Learning and Instruction, 14, 197-213.

Lestari, N. (2017). "Implementasi Model Pembelajaran Kooperatif Tipe Teams Games Tournament untuk Meningkatkan Aktivitas Belajar dan
Hasil Belajar Akuntansi Siswa Kelas XI Akuntansi 3 SMK Negeri 1 Godean Tahun Ajaran 2016/2017". Skripsi: FE UNY.

Noor, K.B.N. (2018). "Pengembangan Media Pembelajaran Interaktif Berbasis Komputer menggunakan Lectora Inspire Software pada Mata Pelajaran Akuntansi Dasar untuk Meningkatkan Motivasi Belajar Siswa Kelas X Akuntansi 1 SMK Muhammadiyah 1 Yogyakarta". Skripsi: FE UNY.

Mulyasa. (2010). Kurikulum Yang Disempurnakan: Pengembangan Standar Kompetensi dan Kompetensi Dasar. Bandung: PT Remaja Rosdakarya.

Rusman (2016). Seri Manajemen Sekolah Bermutu Model-model Pembelajaran Mengembangkan Profesionalisme Guru. Jakarta: PT RajaGrafindo Persada.

Rachmawati, H. (2018). "Implementasi Model Pembelajaran Kooperatif Tipe Team Games Tournament (TGT) dengan Media Pembelajaran Kotak dan Kartu Misteri (Kokami) untuk Meningkatkan Motivasi Belajar Dan Hasil Belajar Kelas X Akuntansi Di SMK Muhammadiyah 1 Wates Tahun Ajaran 2017/2018”. Skripsi: FE UNY.

Sanjaya, W. (2013). Strategi Pembelajaran Berorientasi Standar Proses Pendidikan.Jakarta: Kencana Prenada Media Group.

Slavin, R.E. (2010). Cooperative Learning Teori Riset dan Praktik (Alih bahasa: Narulita Yusron). Bandung: Nusa Media.

Suarjana. (2000). Model Pembelajaran Kooperatif Teams Games Tournament. Jakarta: Balai Pustaka. 
Sudjana, N. (2016). Penilaian Hasil Proses Belajar Mengajar. Bandung: PT Remaja Rosdakarya.

Sugiyono. (2015). Statistika untuk Penelitian. Bandung: Alfabeta.

Taniredja, dkk. (2012). Model-Model Pembelajaran Inovatif. Bandung: Alfabeta.
Widyastuti, N.A. (2017). "Implementasi Model Pembelajaran Kooperatif Teams Game Tournament (TGT) Dengan Perminan Tic Tac Toe untuk Meningkatkan Minat dan Hasil Belajar Ekonomi Siswa Kelas X MIA 4 SMA Negeri 1 Sewon Tahun Ajaran 2016/2017”. Skripsi: FE UNY. 